\title{
STUDY OF THE HEPATITIS C VIRUS IN THE REPUBLIC OF MACEDONIA
}

\author{
Kiprijanovska $\mathrm{S}^{1}$, Sukarova-Stefanovska $\mathrm{E}^{1}$, Noveski $\mathrm{P}^{1}$, \\ Chalovska V², Polenakovic $\mathrm{M}^{1}$, Plaseska-Karanfilska $\mathrm{D}^{1, *}$
}

\begin{abstract}
*Corresponding Author: Professor Dr. Dijana Plaseska-Karanfilska, Research Centre for Genetic Engineering and Biotechnology "Georgi D. Efremov", Macedonian Academy of Sciences and Arts, Krste Misirkov 2, Skopje 1000, Republic of Macedonia; Tel: +389(0)2 3235410; Fax: +389 (0)2 3115434; E-mail: dijana@manu.edu.mk
\end{abstract}

\begin{abstract}
Hepatitis $\mathrm{C}$ virus (HCV) is a major public health problem. It is a leading cause of chronic liver disease and the most common indication for liver transplantation. The therapy for eradication of $\mathrm{HCV}$ infection is successful in only $50.0-80.0 \%$ of patients and is highly dependent on the HCV genotype.

Molecular detection and characterization of $\mathrm{HCV}$ in the Republic of Macedonia started in 1990. Since then, more than 4000 samples have been analyzed at the Research Centre for Genetic Engineering and Biotechnology (RCGEB) "Georgi D. Efremov," Skopje, Republic of Macedonia. The prevalence of HCV infections in the healthy population of the Republic of Macedonia was found to be $0.4 \%$, while it varies between 23.0 and $43.0 \%$ in different at-risk groups of patients.

The prevalence of HCV genotypes, according to associated risk factors in $\mathrm{HCV}$ infected patients from the Republic of Macedonia, was analyzed. We found genotype 1 to be predominant in a group of hemodialysis patients, while genotype 3 was predominant in intravenous (IV) drug users.

1 Research Centre for Genetic Engineering and Biotechnology "Georgi D. Efremov," Macedonian Academy of Sciences and Arts, Skopje, Republic of Macedonia

2 Clinic of Gastroenterohepatology, Medical Faculty, Skopje, Republic of Macedonia
\end{abstract}

Association of six polymorphisms in the Oligoadenylate synthetase (OASL)-like interferonstimulated gene with a sustained virological response was also analyzed. Our preliminary results suggest that non ancestral alleles in four of the six studies polymorphisms in $O A S L$ gene are associated with sustained virological response among HCV infected patients in R. Macedonia.

Keywords: Hepatitis C virus (HCV) Genotyping, Intravenous (IV) drug users, HCV therapy, Oligoadenylate synthetase $(O A S L)$ like interferon stimulated gene

\section{INTRODUCTION}

Hepatitis $\mathrm{C}$ virus (HCV) is a major health problem affecting 170 million people worldwide. The prevalence rate is about $1.0 \%$ in western countries and North America, $3.0-4.0 \%$ in some Mediterranean and Asian countries and up to $10.0-20.0 \%$ in parts of central Africa [1]. The HCV infection is the leading cause of chronic hepatitis worldwide, progressing to liver cirrhosis, and hepatocellular carcinoma in approximately $20.0 \%$ of patients [2-5].

Hepatitis $\mathrm{C}$ virus was the first virus discovered by molecular cloning [6]. Hepatitis $\mathrm{C}$ virus is an enveloped, positive-sense RNA virus, belonging to the Hepacivirus genus of the Flaviviridae family [6]. The genome is approximately $9.6 \mathrm{~kb}$ in size 
and contains an open reading frame (ORF) encoding a large protein precursor [7]. This precursor is cleaved by host and viral proteases into various structural and non structural proteins. The structural proteins are at the 5 ' end and include the capsid or core protein (c), two envelope proteins (E1 and E2) and a small protein of unknown function (P7). The structural proteins are followed by at least six non structural (NS) proteins denoted as NS2, NS3, NS4A, NS4B, NS5A and NS5B [8].

On the basis of phylogenetic analysis of nucleotide sequences, HCV can be divided into six genotypes and several subtypes. The six genotypes differ between each other in 30.0-35.0\% of sequence, while the subtypes differ in $20.0-25.0 \%$ over the complete genome. Different HCV genotypes exhibit different epidemiological and clinical implications. The HCV genotypes 1, 2, and 3 appear to have a worldwide distribution. The HCV genotypes 1 and 3 are the most common genotypes in the United States [9] and in Europe [10,11]. Genotype 3 , which is endemic in Southeast Asia, has been encountered in Europe and the USA, with relatively high frequency in intravenous (IV) drug users [12]. The HCV genotype 4 appears to be prevalent in North Africa and the Middle East [13,14], and genotype 5 predominates in South Africa. Genotype 6, according to different authors, is divided into additional genotypes 7-11 and is mainly found in the HCV populations of Vietnam and Hong Kong [1519]. Hepatitis $C$ virus genotypes have proved to be important epidemiologic marker that can be used to predict success of therapy. The HCV genotype 1 is a more aggressive strain and one that is less likely to respond to interferon treatment than HCV genotypes 2 or 3 . All this information has great significance when planning future strategies for eradication and therapeutic management of $\mathrm{HCV}$.

Molecular detection and characterization of the $\mathrm{HCV}$ infections in the Republic of Macedonia started in 1990. Since then, more than 4000 samples have been analyzed at the Research Centre for Genetic Engineering and Biotechnology (RCGEB) "Georgi D. Efremov," Skopje, Republic of Macedonia. Blood samples were collected by the Clinic of Infection Diseases, Clinic of Gastroenterology and several dialysis centers from the Republic of Macedonia. Amplicor Specimen Preparation and Amplification kit (Roche Diagnostics, Indianapolis, IN, USA) were used for RNA isolation and amplification according to the manufacturer's recommendations. The prevalence of HCV infections in the healthy population of the Republic of Macedonia was found to be $0.4 \%$, while in different at-risk groups of patients such as IV drug users, hemodialysis patients, patients under a blood transfusion regimen and those with unknown factors, the prevalence of $\mathrm{HCV}$ varies between 23.0 and $43.0 \%$ [20].

Genotyping analyses were performed on 1346 patients with a positive HCV-RNA analysis result. The HCV/RNA genotyping was performed with an in-house allele-specific oligonucleotide (ASO) hybridization method using specific oligonucleotide probes for different HCV genotypes [genotype 1 (5'-CGC TCA ATG CCT GGA GAT-3'); HCV2a (5'-CAC TCT ATG CCC GGC CAT-3'), HCV2b (5'-CAC TCT ATA CCC GGC CAT-3'), HCV3 (5'CGC TCA ATA CCC AGA AAT-3') and HCV4a (5'-CAC TCT ATG CCC GGC C-3)].

Genotypes 1 and 3 are predominant in patients from the Republic of Macedonia. Genotype 1 was found in $55.4 \%$ of genotyped patients $(n=714)$, while genotype 3 was found in $44.6 \%$ of genotyped patients $(n=632)$ [20]. There was statistically significant difference between the risk factors analyzed and the acquisition of HCV infection.

Hepatitis $\mathrm{C}$ virus is a highly prevalent infection in chronic dialysis patients (37.7\%) and represents one of the major problems of hemodialysis units in our country [21]. Genotype 1 is predominant in this group of patients $(90.7 \%)$. A combined infection $(4.6 \%)$ of genotypes 2 and 3 was found in two patients $(4.6 \%)$, and a combined infection of genotypes 1 and 3 was also found in another two patients (4.6\%) [22].

We found predominance of $\mathrm{HCV}$ genotype 3 in HCV-positive IV drug users (93.35\%). High prevalence of genotype 3 in an analyzed group of IV drug users is similar to the pattern of genotypes in IV drug users in both Europe and the USA [12]. The HCV genotype distribution in our patients over the years, shows a shift between the prevalence of genotypes 1 and 3 . The increase of patients with genotype 3 is due to the increasing number of IV drug users analyzed at our center.

Evidence from several studies indicate that interferon signaling pathway genes (IPGs) and interferon stimulated genes (ISGs) are associated with 
the host response to HCV infection. In order to investigate the possible association of six polymorphisms in the $O A S L$-like interferon stimulated gene with a sustained virological response, we studied six single nucleotide polymorphisms in the $O A S L$ gene in two groups of patients with an HCV infection: patients who were non responders to the therapy, and those who had sustained a virological response to the therapy. Our preliminary results suggest that non ancestral alleles in four of the six studied polymorphisms in the $O A S L$ gene are associated with sustained virological response to pegylated interferon $\alpha-2 \mathrm{a}(\mathrm{Peg}-\mathrm{IFN}-\alpha)$ plus ribavirin therapy [23].

\section{REFERENCES}

1. World Health Organization (WHO). Global surveillance and control of hepatitis C. Report of a WHO Consultation organized in collaboration with the Viral Hepatitis Prevention Board, Antwerp, Belgium. J Viral Hepat. 2001; 6:35-47.

2. Seeff LB. Natural history of viral hepatitis, type C. Semin Gastrointest Dis. 1995; 6(1): 20-27.

3. Di Bisceglie AM. Hepatitis $C$ and hepatocellular carcinoma Semin Liver Dis. 1995; 15(1): 64-69.

4. Kuo G, Choo QL, Alter HJ, et al. An assay for circulating antibodies to a major etiologic virus of human nonA, non-B hepatitis. Science. 1989; 244(4902): 362-364.

5. Lauer GM, Walker BD. Hepatitis $C$ virus infection. N Engl J Med. 2001; 345(1): 41-52.

6. Choo QL, Kuo G, Weiner AJ, Overby LR, Bradley DW, Houghton M. Isolation of a cDNA clone derived from a blood-borne non-A, non-B viral hepatitis genome. Science. 1989; 244(4902): 359-362.

7. Houghton $\mathrm{M}$. Hepatitis $\mathrm{C}$ virus, In: Fields $\mathrm{BN}$, Knipe DM, Howley PM, Chanock RH, Eds. Fields Virology, 3rd ed. Philadelphia: Lippincott-Raven. 1996: 1035-1058.

8. Al-Faleh F, Ramia S. Hepatitis C virus infection in Saudi Arabia: a review. Ann Saudi Med. 1997; 17(1): 77-82.

9. Bhattacherjee V, Prescott LE, Pike I, et al. Use of NS-4 peptides to identify type-specific antibody to genotypes 1, 2, 3, 4, 5 and 6. J Gen Virol. 1995; 76(Pt 7): $1737-1748$.

10. McOmish F, Yap PL, Dow BC, et al. Geographical distribution of hepatitis $\mathrm{C}$ virus genotypes in blood donors: an international collaborative survey. J Clin Microbiol. 1994; 32(4): 884-892.0

11. Mondelli MU, Silini E. Significance of hepatitis C virus genotypes. Viral Hepat Rev. 1995; 1(Suppl 1): 111-120.

12. Silini E, Bono F, Cividini A, et al. Molecular epide- miology of hepatitis $\mathrm{C}$ virus infection among intravenous drug users. J Hepatol. 1995; 22(6): 691-695.

13. Abdulkarim AS, Zein NN, Germer JJ, et al. Hepatitis $\mathrm{C}$ virus genotypes and hepatitis $\mathrm{G}$ virus in hemodialysis patients from Syria: identification of two novel hepatitis C virus subtypes. Am J Trop Med Hyg. 1998; 59(4): 571-576.

14. Chamberlain RW, Adams N, Saeed AA, Simmonds P, Elliot RM. Complete nucleotide sequence of a type 4 hepatitis $\mathrm{C}$ virus variant, the predominant genotype in the Middle East. J Gen Virol. 1994; 78(Pt 6):1341-1347.

15. Simmonds P, Holmes EC, Cha TA, et al. Classification of hepatitis $\mathrm{C}$ virus into six major genotypes and a series of subtypes by phylogenetic analysis of the NS-5 region. J Gen Virol. 1993; 74(Pt 11): 23912399.

16. Cha TA, Kolberg J, Irvine B, et al. Use of a signature nucleotide sequence of hepatitis $\mathrm{C}$ virus for detection of viral RNA in human serum and plasma. J Clin Microbiol. 1992; 29(11): 2528-2534.

17. Tokita HS, Shrestha M, Okamoto H, et al. Hepatitis $\mathrm{C}$ virus variants from Nepal with novel genotypes and their classification into the third major group. J Gen Virol. 1994; 75(Pt 4): 931-936.

18. Tokita HH, Okamoto $\mathrm{H}$, Iizuka $\mathrm{H}$, et al. Hepatitis $\mathrm{C}$ virus variants from Jakarta, Indonesia classifiable into novel genotypes in the second (2e and $2 \mathrm{f}$ ), tenth (10a) and eleventh (11a) genetic groups. J Gen Virol. 1996; 77(Pt 2): 293-301.

19. Tokita HH, Okamoto H, Iizuka J, Kishimoto F, Tsuda $\mathrm{Y}$, Mayumi M. The entire nucleotide sequences of three hepatitis $\mathrm{C}$ virus isolates in genetic groups 7-9 and comparison with those in the other eight genetic groups. J Gen Virol. 1998; 79(Pt 8): 1847-1857.

20. Kiprijanovska S. Prevalence and genotyping of HCV infection in patients belonging to different risk groups in the Republic of Macedonia. Prilozi. 2012; (submitted)

21. Simjanovska LJ, Porcu K, Amitov V, Efremov GD, Polenakovic M. Reverse transcriptase/polymerase chain reaction analysis of hemodialysis ultrafiltrates and sera of hepatitis $\mathrm{C}$ virus positive patients. Int $\mathrm{J}$ Artif Organs. 2004; 27(1): 35-39.

22. Popovski Z, Dimovski A, Simjanovska L, et al. Molecular detection and characterization of hepatitis $\mathrm{C}$ virus in the Republic of Macedonia. Makedonski medicinski pregled. 1996; 50(4):85-90.

23. Kiprijanovska S, Noveski P, Chalovska V, Polenakovic M, Plaseska-Karanfilska D. Association of $O A S L$ gene with chronic HCV therapy response to pegylated interferon- $\alpha$ and ribavirin. Proceedings of the 39th European Society for Artificial Organs Congress, Rostock, Germany, 26-29 September 2012; (submitted). 